\title{
Variasi dan Sebaran Litologi Batugamping di Kecamatan Todanan, Kabupaten Blora, Jawa Tengah
}

Reddy Setyawan $^{1 *}$, Abdurrahman Hakim ${ }^{1}$, Afif Sulestianson ${ }^{1}$, Alfa Aulia Satria Bagaskara ${ }^{1}$, Fitria Febyani ${ }^{1}$, Hasbi As-Siddiqi Sutandiono ${ }^{1}$, Kristian Jhonson Napitupulu ${ }^{1}$, Nurjayanti ${ }^{1}$.

${ }^{1}$ Departemen Teknik Geologi, Fakultas Teknik, Universitas Diponegoro, Semarang

\begin{abstract}
Abstrak
Daerah Todanan merupakan salah satu wilayah di Kabupaten Blora. Todanan merupakan wilayah dataran perbukitan landai yang secara geologi masuk ke dalam Zona Rembang. Zona Rembang merupakan bagian dari cekungan sedimentasi Jawa Timur bagian utara (East Java Geosyncline). Cekungan ini terbentuk pada Oligosen Akhir yang berarah Timur. Tujuan dilakukan penelitian ini adalah untuk mengetahui variasi litologi batugamping, umur dan fasies dari batugamping yang diharapkan dapat memperkaya pengetahuan geologi di lokasi ini. Metode penelitian yang digunakan adalah observasi lapangan untuk mendapatkan data variasi litologi. Sampel batuan yang didapatkan dari lapangan selanjutnya dilakukan analisis petrografi dan mikrofosil. Hasil dari observasi di lapangan, dapat diketahui kondisi geomorfologi, variasi litologi dan kondisi struktur geologi di lokasi penelitian. Geomorfologi lokasi penelitian terbagi menjadi Dataran Landai Denudasional, Bergelombang Miring Denudasional, Berbukit Bergelombang Karst, Bergelombang Miring Struktural Karst, Bergelombang Miring Struktural Lembah Sinklin, dan Bergelombang Miring Struktural Bukit Antiklin. Struktur geologi cukup sulit dilakukan di lapangan, karena sebagian besar area di lokasi penelitian tertutup oleh hutan jati, sawah, dan pemukiman. Variasi litologi yag ditemukan di lapangan adalah Satuan Batupasir Karbonatan, Satuan Batugamping Kalkarenit, Satuan Lempung Karbonatan, Satuan Batugamping Wackestone, Satuan Batugamping Grainstone, dan Satuan Batugamping Packestone. Satuan litologi Wackestone, Grainstone dan Packestone terendapkan di fasies fore reef.
\end{abstract}

Kata kunci: Todanan; Geosinklin Jawa Timur; Zona Rembang; batugamping; batupasir.

\begin{abstract}
Todanan area is one of the regions in Blora Regency. Todanan is a sloping hilly terrain that is geologically belong to the Rembang zone. The Rembang Zone which is part of the sedimentary basin of the East Java region (East Java Geosyncline). This basin formed in the Late Oligocene. The purpose of this research is to find out variations of limestone lithology which will hopefully be able to enrich geological knowledge in this location. The research method used was field observations to obtain lithology variation data. Rock samples obtained from the field were then analyzed by petrographic and microfossils. The results of observations composed in the field can be known geomorphological conditions, lithological variations and geological structure conditions at the study location. The geomorphology of the study site is divided into Denudational Sloping Plain, Denudational Corrugated Slope, Karst Corrugated Hill, Karst Corrugated Structural Slope, Structural Synclinal Valley Corrugated Slope, and Structural Anticlinal Hill Corrugated Slope. Geological structure is quite difficult to find in the field, because most of the area in the study site is covered by teak forests, rice fields, and settlements. Lithological variations found in the field are the Carbonate Sandstone, Calcarenite Limestone Unit, Carbonate Clays Unit, Wackestone Limestone Unit, Grainstone Limestone Unit, and Packestone Limestone Unit. The Wackestone, Grainstone and Packestone lithology units are deposited in the Fore reeffacies.
\end{abstract}

Keywords: Todanan; East Java Geosyncline; Rembang zone; limestone; sandstone. 


\section{PENDAHULUAN}

Daerah Todanan merupakan salah satu wilayah di Kabupaten Blora. Todanan merupakan wilayah dataran perbukitan landai yang secara geologi masuk ke dalam zona Rembang. Setiap daerah pasti memiliki kondisi geologi tertentu yang dapat kita pelajari untuk mengetahui potensi positif dan negatif wilayah tersebut. Luasan area yang tersusun oleh batugamping membuat daerah tersebut cukup potensial untuk dilakukan penambangan batugamping.

Batugamping secara ekonomis dalam skala besar dapat dimanfaatkan sebagai bahan baku industri semen. Dalam skala yang lebih kecil melalui penambangan galian $\mathrm{C}$ dapat dimanfaatkan sebagai bahan bangunan, bahan pembasmi hama, bahan pupuk insektisida dan bahan penjernihan air.

Pengetahuan geologi di suatu wilayah dapat menjadi pertimbangan dalam melakukan pengembangan dalam wilayah tersebut. Perbedaan yang mencolok perihal sifat litologi dari endapan - endapan yang berada pada Mandala Kendeng, Mandala Rembang, dan Paparan laut Jawa yaitu sedimen. Mandala Kendeng pada umumnya terisi oleh endapan arus turbidit yang selalu mengandung batuan piroklastik dengan selingan napal dan batuan karbonat serta merupakan endapan laut dalam. Umumnya sedimen-sedimen tersebut terlipat kuat dan tersesar sungkup ke arah Utara, sedangkan Mandala Rembang memperlihatkan batuan dengan kadar pasir yang tinggi disamping meningkatnya kadar karbonat serta menghilangnya endapan piroklastik. Sedimen-sedimen Mandala Rembang memberi kesan berupa endapan laut dangkal yang tidak jauh dari pantai dengan kedalaman dasar laut yang tidak seragam. Hal ini disebabkan oleh adanya sesar-sesar bongkah (Block faulting) yang mengakibatkan perubahan-perubahan fasies serta membentuk daerah tinggian atau rendahan. Daerah lepas pantai laut Jawa pada umumnya ditempati oleh endapan paparan yang hampir seluruhnya terdiri dari endapan karbonat.

Ramdaniya dkk. (2018) telah melakukan penelitian mengenai geologi daerah Kanjengan di Kecamatan Todanan. Penelitian tersebut menyebutkan bahwa Daerah penelitian berdasarkan litostratigrafi dapat dibagi menjadi 2 (dua) satuan dari tua ke muda, Satuan Batuan Batupasir sisipan Batulempung dan Batugamping (Formasi Ngrayong) yang diendapkan di lingkungan laut dangkal (Neritik Tepi - Neritik Tengah) pada umur Miosen Tengah atau N9-N11.

Aditya (2019) juga telah melakukan analisis di Formasi Wonocolo dan Ledok di Kecamatan Todanan. Penelitian tersebut menyebutkan bahwa Satuan litostratigrafi tidak resmi dengan urutan dari tua ke muda yaitu Satuan batupasir-kuarsa Ngrayong berumur Miosen Tengah (N10-N12), Satuan

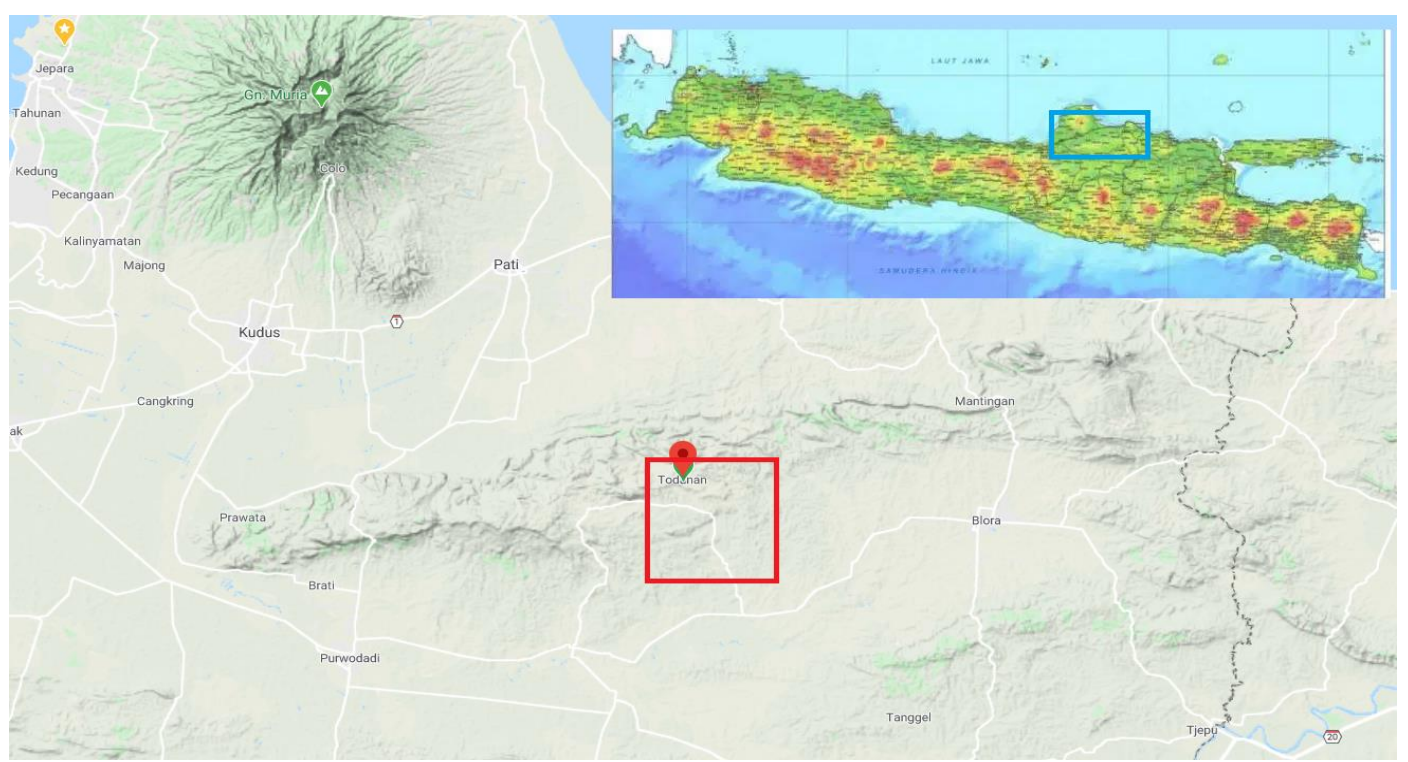

Gambar 1. Peta lokasi daerah penelitian di daerah Todanan ditandai dengan kotak merah. 
Batugamping-klastik Bulu berumur Miosen Tengah (N12-N13), Satuan Batulempungkarbonatan Wonocolo Miosen Tengah Miosen Akhir (N13-N18), Satuan Batupasirkarbonatan Ledok berumur Miosen Akhir (N18-N21), dan Satuan Endapan Aluvial berumur Holosen.

\section{METODOLOGI}

Data-data yang digunakan dalam penelitian ini terbagi menjadi dua, yaitu data primer dan data sekunder. Data primer merupakan data yang didapatkan dari pengamatan langsung di lapangan dan juga sampel batuan yang didapatkan dari pengamatan di lapangan. Data sekunder yang digunakan berupa data geologi regional berupa peta geologi regional.

Pengamatan lapangan dilakukan untuk mengetahui kondisi secara langsung di lapangan. Data-data yang didapatkan dari observasi di lapangan berupa deskripsi batuan dan pengukuran kedudukan batuan. Dalam melakukan observasi lapangan didapatkan 428 titik pengamatan. Sampel batuan yang didapatkan dari hasil observasi lapangan kemudian dipilih untuk dianalisis lebih lanjut berupa analisis petrografi dan analisis mikrofosil berjumlah 19 sampel. Sampel batuan yang dianalisis petrografikan digunakan untuk menentukan variasi litologi yang nantinya akan dapat diketahui sebaran dari tiap variasi litologinya. Analisis fosil digunakan untuk menentukan batimetri perairan pada saat material sedimen diendapkan dan juga digunakan untuk menentukan umur dari tiap satuan batuan yang ditemukan di lapangan.

\section{HASIL}

Hasil dari observasi yang telah dilakukan di lapangan, dapat diketahui kondisi geomorfologi, variasi litologi dan kondisi struktur geologi di lokasi penelitian. Penentuan bentuk lahan menggunakan klasifikasi Bentuk Muka Bumi (Brahmantyo dan Bandono, 2006), sedangkan pengklasifikasian kelerengan menggunakan klasifikasi van Zuidam (1985). Geomorfologi lokasi penelitian terbagi menjadi Dataran Landai Denudasional, Bergelombang Miring Denudasional, Berbukit Bergelombang Karst, Bergelombang Miring Struktural Karst, Bergelombang Miring Struktural Lembah Sinklin, dan Bergelombang Miring Struktural Bukit Antikllin.
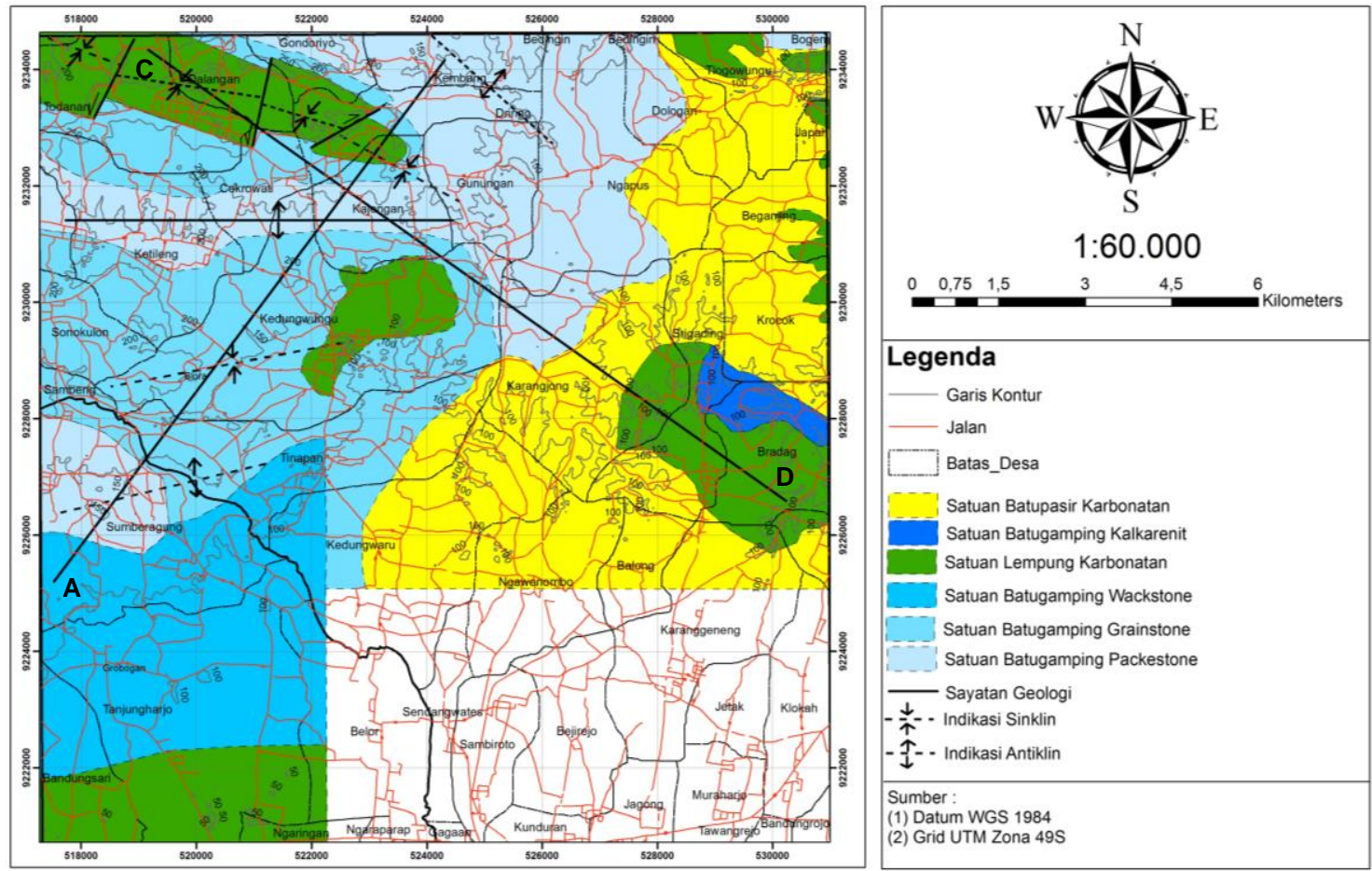

Gambar 2. Peta geologi variasi litologi di lokasi penelitian berdasarkan observasi lapangan yang kemudian dilakukan analisis petrografi dan mikrofosil. 


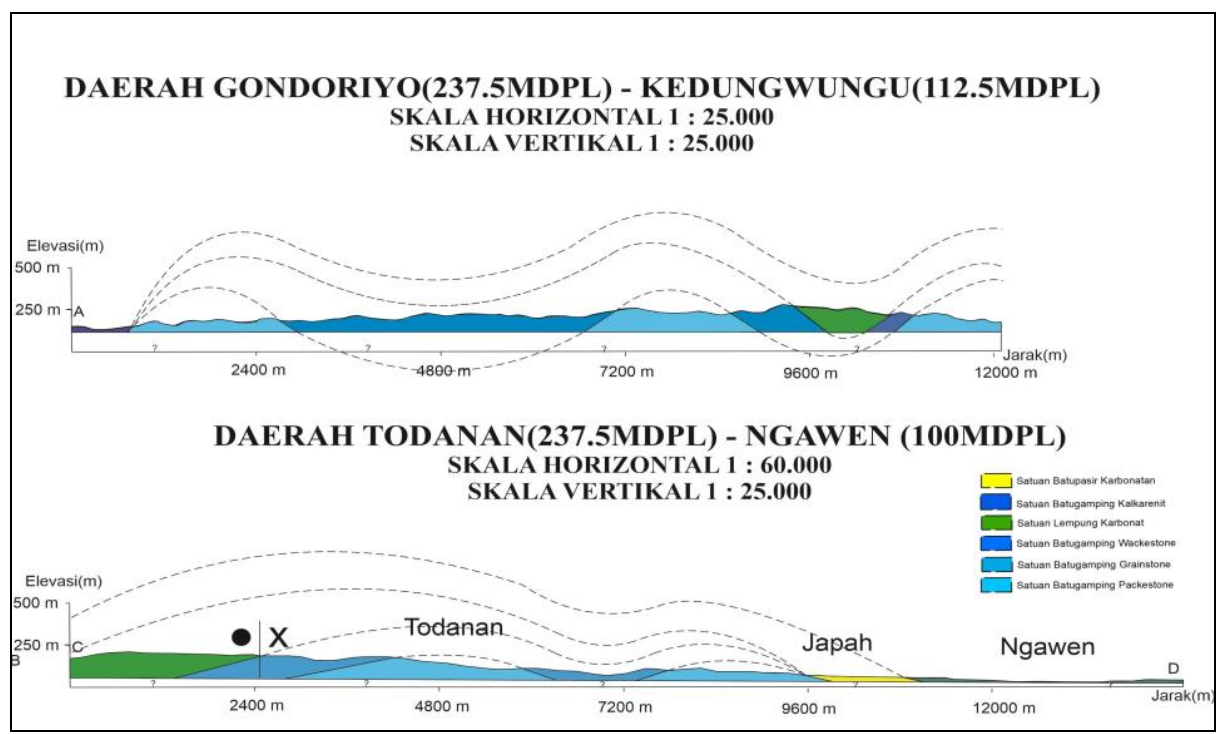

Gambar 3. Sayatan geologi yang memotong setiap satuan litologi di lokasi penelitian.

Penamaan variasi satuan batuan yang di dapatkan di daerah penelitian tidak menggunakan penamaan formasi seperti yang tercantum dalam Stratigrafi Regional Rembang oleh Pringgowrawiro (1983).

Litologi yang ditemukan di lapangan secara umum merupakan bagian dari Formasi Ngrayong, Formasi Bulu, Formasi Wonocolo, Formasi Ledok, dan Formasi Tawun. Variasi litologi yag ditemukan di lapangan adalah Satuan Batupasir, Karbonatan, Satuan batugamping Kalkarenit, Satuan Lempung Karbonatan, Satuan Batugamping Wackestone, Satuan Batugamping Grainstone, dan Satuan Batugamping Packestone (Gambar 2).

Struktur geologi yang ditemukan di lapangan hanya berupa indikasi dari keberadaan struktur geologi. Penentuan dan analisis struktur geologi cukup sulit dilakukan di lapangan, karena sebagian besar area di lokasi penelitian tertutup oleh hutan jati, sawah, dan pemukiman. Secara umum hanya ditemukan indikasi lipatan, baik antiklin maupun sinklin. Selain lipatan, beberapa sesar minor juga ditemukan setempat di lokasi penelitian

\section{PEMBAHASAN}

\section{Satuan Batupasir Karbonatan}

Secara megaskopis, satuan ini memiliki warna abu-abu kecoklatan, strukturnya massif, serta memiliki tekstur dengan ukuran butir $1 / 4-1 / 2 \mathrm{~mm}$ hingga $1 / 16-1 / 8 \mathrm{~mm}$, bentuk butir yang membulat menunjukkan butiran penyusun batuan telah tertransport dalam jarak yang cukup jauh dari sumber. sortasi atau keseragaman butir pada litologi ini memiliki keseragaman butir yang baik (well sorted). Hubungan antar butir atau kemas, memiliki kemas yang tertutup. Berdasarkan struktur dan tekstur, litologi ini merupakan batupasir. Batuan ini bereaksi dengan larutan $\mathrm{HCl}$ sehingga dapat diketahui bahwa batuan ini memiliki semen bersifat karbonatan.

Hasil pengamatan petrografi diketahui bahwa batuan ini memiliki tekstur umum berupa ukuran butir 1/8-1/4 mm, kemudian sortasi yang baik (well sorted), kemas yang tertutup, bentuk butir yang rounded, serta kontak butir suture. Komposisi yang terlihat dengan jelas pada sayatan tipis ini adalah terdapat material-material pasir serta adanya mineral berupa biotit sebanyak 5\%, kemudian mineral hornblende $10 \%$ serta adanya mineral plagioklas 20\% (Gambar 4). Satuan batuan ini mendominasi sisi timur lokasi penelitian dengan luasan sekitar 25\% dari keseluruhan area. Persebarannya melingkupi Desa Ngawenombo di sisi selatan hingga Tlogowungu di sisi utara.

\section{Satuan Batugamping Kalkarenit}

Secara megaskopis, Satuan Batugamping Kalkarenit ini memiliki warna abu-abu, strukturnya yang massif, serta memiliki tekstur umum dengan ukuran butir 1/16-1/4 mm (Wentworth, 1922), bentuk 


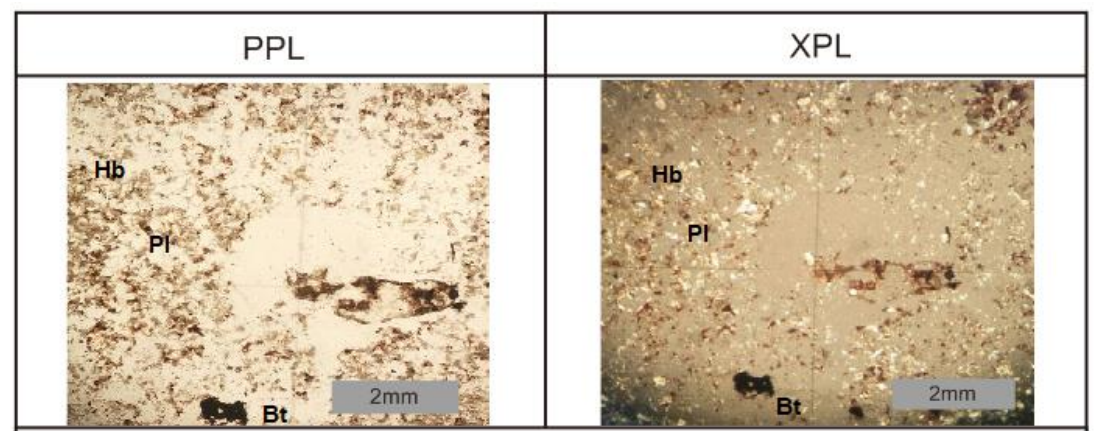

Gambar 4. Sayatan tipis Satuan Batupasir Karbonatan. $(\mathrm{Hb}=$ hornblende; $\mathrm{Pl}=$ plagioklas; $\mathrm{Bt}=$ biotit; PPL=nikol sejajar; $\mathrm{XPL}=$ nikol silang)

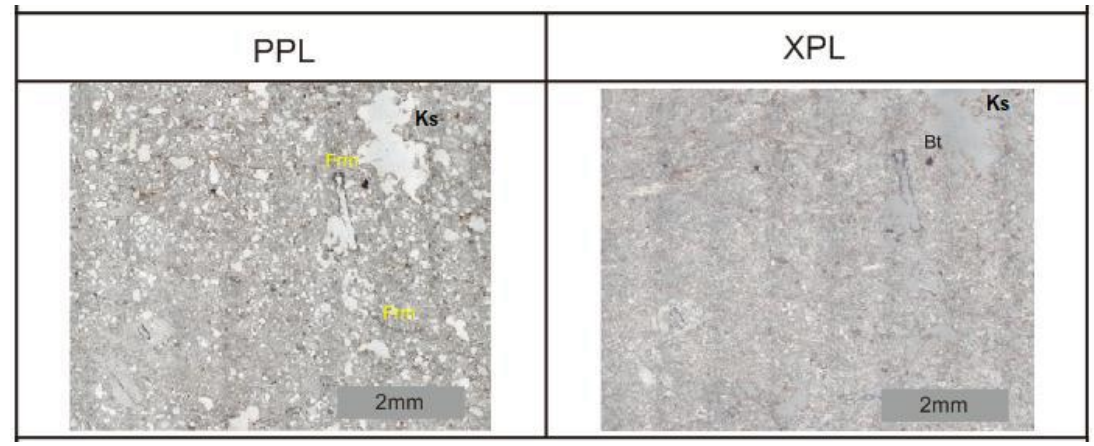

Gambar 5. Sayatan tipis Satuan Batugamping Kalkarenit. (Bt=biotit; Ks=kuarsa; PPL=nikol sejajar; XPL=nikol silang)

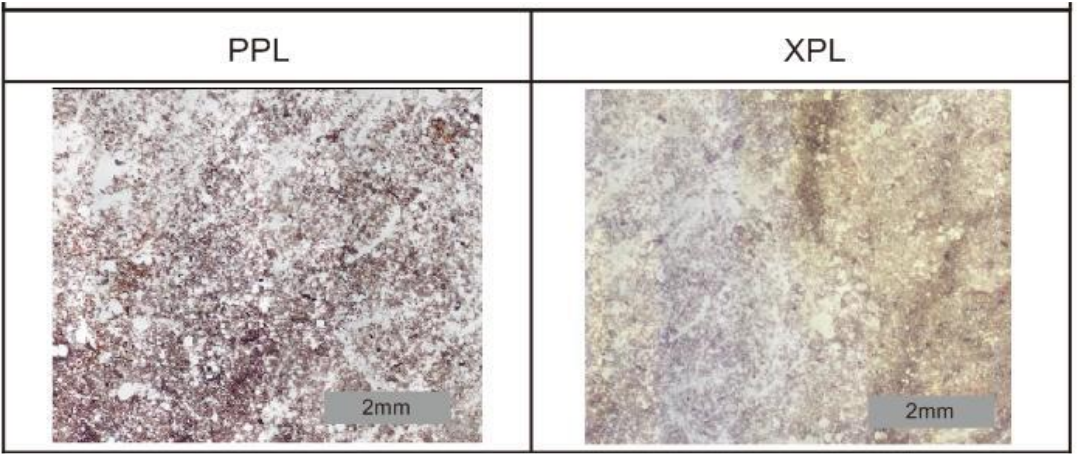

Gambar 6. Sayatan tipis satuan Batulempung Karbonatan. (PPL=nikol sejajar; XPL=nikol silang)

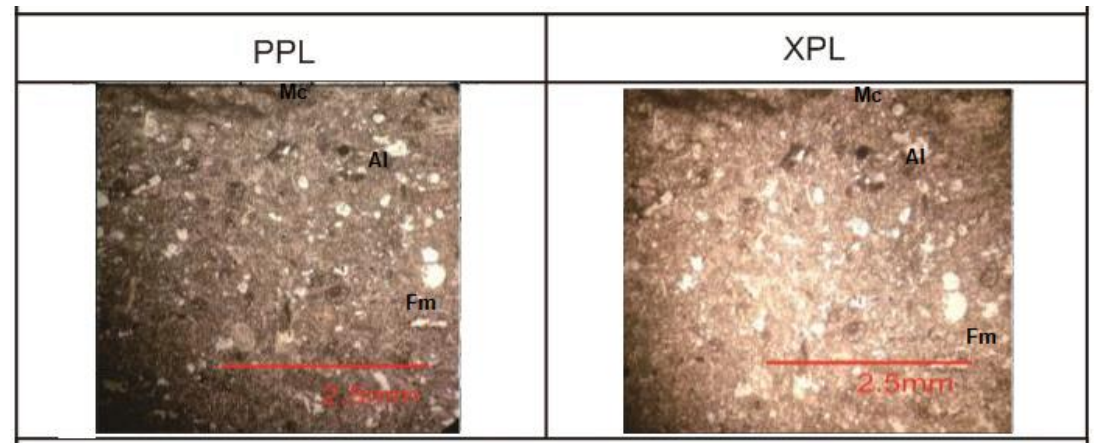

Gambar 7. Sayatan tipis satuan Batugamping Wackestone. $(\mathrm{Al}=\mathrm{alga} ; \mathrm{Fm}=$ foraminifera; $\mathrm{Mc}=$ mikrit; $\mathrm{PPL}=$ nikol sejajar; $\mathrm{XPL}=$ nikol silang) 
butir yang sub-rounded, dikarenakan permukaan pada litologi ini sebagian memiliki fragmen berupa pasir kasar dan hampir membulat. Sortasi atau keseragaman butir pada litologi ini memiliki keseragaman butir yang baik (well sorted), kemudian hubungan antar butir atau kemas,litologi batugamping kalkarenit ini memiliki kemas yang tertutup. Sampel batuan yang didapatkan di lapangan menunjukkan komposisi material berupa lempung dan pasir, serta terdapat kenampakan fosil foraminifera. Berdasarkan struktur dan tekstur yang sudah dipaparkan, dapat disimpulkan bahwa litologi ini merupakan batugamping kalkarenit.

Pengamatan petrografi dilakukan pada sayatan tipis, menunjukkan tekstur umum berupa ukuran butir yang halus 1/16-1/8 mm, sortasi yang baik (well sorted), kemas yang tertutup, bentuk butir yang rounded, serta kontak butir suture. Komposisi yang terlihat dengan jelas pada saytan tipis ini adalah terdapat fragmen cangkang organisme sebanyak 40\% (Gambar 5).

Hasil analisis mikrofosil menunjukkan kisaran umur N15-N17, atau setara dengan umur Miosen Akhir. Fosil yang ditemukan di satuan ini adalah Orbulina universa, Orbulina Bilobata, Globorotalia acostaenea, Hastigerina aequilateral, Globorotalia nepenthes, dan Globorotalia menardi.

Persebaran satuan batuan ini terbatas di sisi timur lokasi penelitian yaitu di bagian utara Desa Bradag dan tenggara desa Srigading. Luasan area satuan ini tidak terlampau luas yaitu kurang dari $10 \%$ sekitar $5 \%$.

\section{Satuan Batulempung Karbonatan}

Secara umum Satuan Batugamping karbonatan yang berada didaerah pemetaan memiliki kenampakan megaskopis berwarna coklat keabuan, dengan strukutr massif, tekstur meilupti: ukuran butir $<1 / 256 \mathrm{~mm}$, bentuk butir subangular, sortasi baik, dan kemas tertutup. Berdasarkan komposisinya litologi ini tersusun atas Mineral berukuran lempung sebanyak $75 \%$, kalsit sebanyak $5 \%$, dan semen sebanyak 20\% (Gambar 6), sehingga dinamakan Batulempung.

Hasil determinasi foraminifera plaktonik didapatkan beberapa jenis spesies seperti Orbulina Universa, Orbulina Bilobata,
Globorotalia acostaenes, Hastigerina aequilateral, Globorotalia nepenthes, dan Globorotalia menardi. Untuk jenis foraminifera bentonik ditemukan bebeapa spesies seperti Cycloclypeus indopacificus, Cycloclypeus inornatus dan Elphidium sagra, sehingga didapatkan hasil berupa umur Miosen akhir hingga Pliosen awal (N15-N18) dan zona batimetrinya adalah zona Neritik.

Luasan area satuan batuan ini berkisar antara $15 \%$ dari total area lokasi penelitian dengan pola persebaran yang tidak terkumpul di satu lokasi. Satuan batuan ini terdapat di Desa Kedungwungu, Dalangan, Bradag, dan setempat di Desa Kedungwungu.

\section{Satuan Batugamping Wackestone}

Satuan Batugamping Kalkarenit tersusun atas litologi yang berwarna coklat kemerahan dalam kondisi fresh dan coklat kehitaman dalam kondisi lapuk, terdapat, secara umum memiliki struktur perlapisan, memiliki ukuran butir 1/4-1/2 mm, sortasi baik, kemas tertutup, bentuk butir sub-angular, terdiri dari atas allochem berupa foraminifera, alga orthochem berupa material berukuran pasir dan semen berupa micrite, sehingga satuan ini bernama batugamping Wackestone (Embry dan Klovan, 1971).

Berdasarkan deskripsi pada batuan ini dapat diketahui tingkat diagenesisnya. Ukuran grain yang dominan kasar menunjukan bahwa jarak transport material penysusun batuan sedimen karbonat ini dengan pusat terumbu relatif dekat, kebundaran subrounded, dan terususn oleh grain berupa organisme yang relatif utuh menunjukan tingkat abrasi kurang intens atau pengaruh gelombang tidak terlalu dominan sehingga organisme tidak hancur. Pemilahan poorly-sorted dengan kemas terbuka menunjukan material yang terendapakan berbeda energi trensportnya sehingga terendapkan material dengan ukuran yang beragam. Kontak butir concav-convex menunjukan bahwa tingkat kompaksi intensif, hal inilah yang mengakibatkan butiran penyusun batuan ini termampatkan. Selain itu, convav-convex menunjukan proses pelarutan. Komposisi batuan ini grain suported, orthocem berupa micrite menunjukan lingkungan pengendapan berenergi rendah sehingga micrite terbentuk 


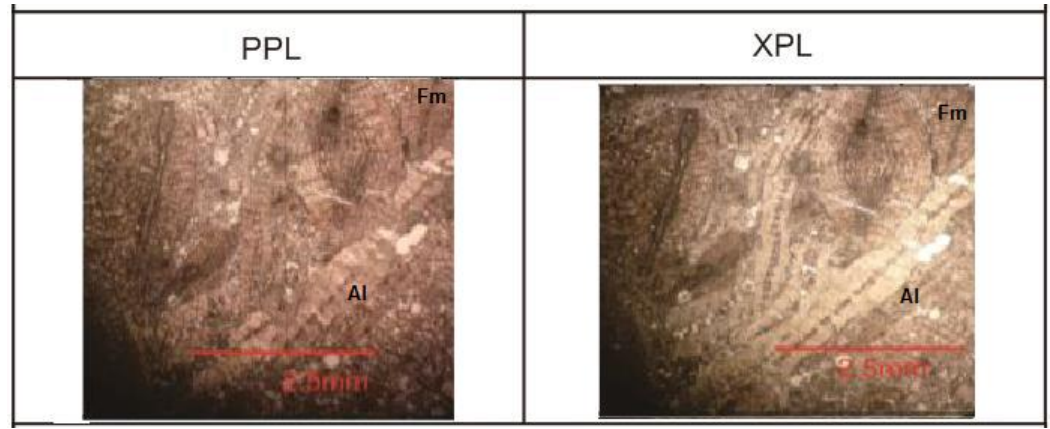

Gambar 8. Sayatan tipis Satuan Batugamping Grainstone. (Al=alga; Fm=foraminifera; PPL=nikol sejajar; XPL=nikol silang)

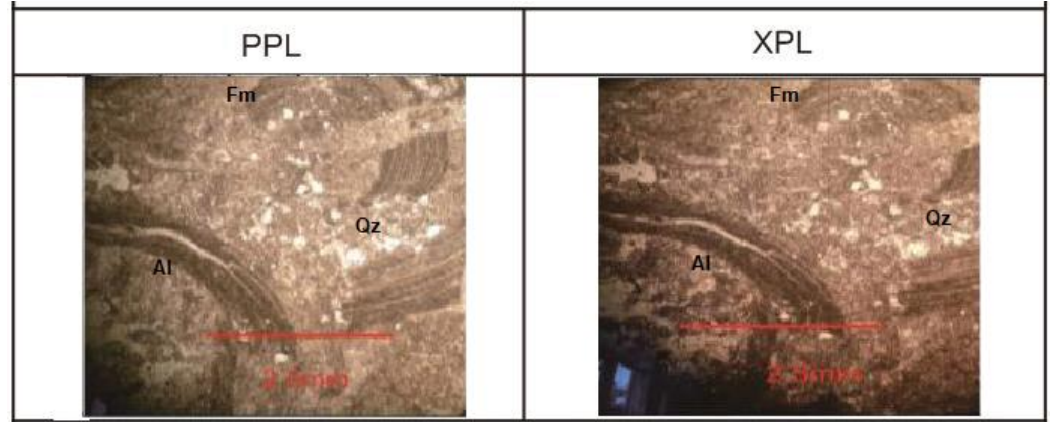

Gambar 9. Sayatan tipis Satuan Batugamping Packestone. $(\mathrm{Al}=\mathrm{alga} ; \mathrm{Fm}=$ foraminifera; $\mathrm{Qz}=\mathrm{kuarsa}$; PPL=nikol sejajar; XPL=nikol silang)

pada kondisi air yang tenang. Orthocem berupa micrite menunjukan bahwa diagenesis pada batuan ini masih rendah. Semen kalsit menunjukan bahwa telah terjadi rekristalisasi material authogenic dari mineral aragonit maupun dolomit. Semen kalsit terbentuk hasil pelarutan batuan.

Hasil determinasi foraminifera plaktonik didapatkan beberapa jenis spesies seperti Orbulina universa, Orbulina bilobata, Globorotalia acostaenes, Hastigerina aequilateral, Globorotalia nepenthes, dan Globorotalia menardi. Hasil analisis foraminifera bentonik ditemukan bebeapa spesies seperti Cycloclypeus indopacificus, Cycloclypeus inornatus dan Elphidium sagra didapatkan hasil berupa umur Miosen Akhir (N17-N18) dan ligkungan pengendapan berupa zona Neritik.

Satuan batuan ini berada di sisi barat daya di Desa Tanjungharjo lokasi penelitian dengan luasan area sekitar 20\%. Satuan batuan ini telah banyak dimanfaatkan sebagai pemukiman dan pabrik.

\section{Satuan Batugamping Grainstone}

Secara umum Satuan Batugamping Grainstone yang berada didaerah pemetaan memiliki kenampakan megaskopis berwarna kuning kecoklatan sampai putih, dengan struktur massif, tekstur meliputi: ukuran butir 0,5-1 mm, bentuk butir sub-angular, sortasi buruk, dan kemas tertutup. Berdasarkan komposisinya litologi ini tersusun atas foraminifera sebanyak 50\%, sedangkan matriksnya tersusun atas mikrite atau lumpur karbonat sebanyak $10 \%$, sparit sebanyak $37 \%$ dan semen kalsit sebanyak 3\% (Gambar 8), sehingga dinamakan Grainstone (Embry dan Klovan 1971).

Berdasarkan analisis petrologi dan mikrofosil diketahui bahwa litologi ini kaya akan foraminifera besar dan foraminifera planktonik maupun bentonik. Berdasarkan hasil analisis mikrofosil Foraminifera planktonic ditemukannya fosil Orbulina universa, Orbulia bilobata, Globorotalia siakensis, Orbulina suturalis, Globorotalia menardi dan Globigerinoides immaturus, sehingga dapat diketahui umur dari litologi ini yaitu pada Miosen Tengah ( N12-N14). Hasil analisis mikrofosil Foraminifera Bentonik didapatkan fosil Cyclopeous indopasificus, Numulites sp, Anomalinoides rubiginosus, Bulmina gibba dan Amphycoryna scalaris, sehingga dapat 
ditentukan lingkungan pengendapannya yaitu berada di lingkungan Neritik.

Luasan area satuan batuan ini kurang lebih 20\% dengan sebaran di bagian tengah lokasi penelitian. Satuan batuan ini ditemukan di Desa Kedungwungu, Kedungwaru, Sambeng dan Cokrowati. Satuan batuan Batugamping Grainstone telah dimanfaatkan untuk tambang rakyat yang digunakan untuk bahan bagunan dan penguatan jalan.

\section{Satuan Batugamping Packestone}

Kenampakan megaskopis satuan ini berwarna coklat kemerahan, dengan strukutr massifberlapis, tekstur meliputi: ukuran butir 0,5-1 $\mathrm{mm}$, bentuk butir subangular, sortasi buruk, dan kemas tertutup. Berdasarkan komposisinya litologi ini tersusun atas Foraminifera sebanyak 40\%, kuarsa 5\%, dan alga 10\% (Gambar 9) sedangkan matriksnya tersusun atas micrite atau lumpur karbonat sebanyak $42 \%$ dan semen kalsit sebanyak 3 $\%$, sehingga dinamakan Packestone (Embry dan Klovan 1971) pada beberapa tempat ditemukan cangkang pelecypoda.

Berdasarkan analisis petrologi dan mikrofosil didapati bahwa litologi ini kaya akan foraminifera besardan foraminifera planktonik maupun bentonik. Berdasarkan hasil analisis mikrofosil Foraminifera planktonic ditemukannya fosil Orbulina universa, Orbulia bilobata, Globorotalia siakensis, Orbulina suturalis, Globigerinoides subquadratus dan Globigerinoides immaturus, sehingga dapat diketahui umur dari litologi ini yaitu pada Miosen Tengah (N9-N13). Berdasarkan analisis mikrofosil Foraminifera Bentonik didapatkan fosil Anomalinoides rubiginosus, Cyclopeous indopasificus, Numulites sp, Lepidocyclina pustulosa dan Amphycoryna scalaris, sehingga dapat ditentukan lingkungan pengendapannya yaitu berada di lingkungan Neritik.

Satuan batuan ini ditemukan di bagian tengah hingga utara lokasi penelitian dengan luasan area sekitar $15 \%$ dengan sebaran meliputi desa Gondoriyo, Kembang, Gunungan dan Ngapus. Satuan ini berkontak dengan Satuan Batugamping Grainstone di sisi barat dan Batupasir kalkarenit di sisi timur.

\section{Analisis Lingkungan Pengendapan}

Analisis mikrofosil dari sampel batuan di lapangan, hampir dapat dilakukan di hampir semua satuan batuan. Berdasarkan fasies terumbu Pomar dkk (2004) satuan litologi Grainstone terendapkan di fasies fore reef bagian atas yang diinterpretasikan satuan litologi ini terendapkan dengan arus yang lebih kencang sehingga keberadaan micrite sangat kecil, semakin dalam fasiesnya menyebabkan keberadaan matrixs berupa micrite yang semakin besar dikarenakan arus yang semakin tenang ke arah dalam. Pada fasies ini material karbonatnya berasal dari pecahan ataupun fragmen dari fasies reef front.

Berdasarkan deskripsi pada batuan ini dapat diketahui tingkat diagenesisnya. Ukuran butir yang dominan kasar menunjukan bahwa jarak transport material penyusun batuan sedimen karbonat ini dengan pusat terumbu relatif dekat, kebundaran angular, dan terususn oleh butir berupa organisme yang utuh menunjukan tingkat abrasi kurang intens atau pengaruh gelombang tidak dominan. Pemilahan poorlysorted dengan kemas terbuka menunjukan material yang terendapakan berbeda energi trensportnya sehingga terendapkan material dengan ukuran yang beragam. Kontak butir poin menunjukan bahwa tingkat kompaksi kurang intensif, hal inilah yang mengakibatkan grain-grain penyusun batuan ini sedikit termampatkan. orthocem berupa sparite menunjukan lingkungan pengendapan berenergi tinggi. Sparite menunjukan proses diagenesis tinggi. Semen kalsit menunjukan bahwa telah terjadi rekristalisasi material authogenic dari mineral aragonit maupun dolomit. Semen kalsit terbentuk hasil pelarutan batuan dengan air meteorik.

Jika melihat fasies terumbu Pomar dkk. (2004) (Gambar 10), satuan litologi packestone ini terendapkan di fasies fore reef bagian dalam yang semakin dalam fasiesnya menyebabkan keberadaan matriks berupa micrite yang semakin besar dikarenakan arus yang semakin tenang ke arah dalam. Pada fasies ini material karbonatnya berasal dari pecahan ataupun fragmen dari fasies reef front. 
Tabel 1. Distribusi Foraminifera untuk menentukan umur setiap satuan batuan di lokasi penelitian

\begin{tabular}{|c|c|c|c|c|c|c|c|c|c|c|c|c|c|c|c|c|c|c|c|c|c|c|c|c|c|}
\hline \multirow{3}{*}{ Litologi } & \multirow{3}{*}{ No } & \multirow{3}{*}{ Organisme } & \multirow{2}{*}{\multicolumn{3}{|c|}{ Oligocene }} & \multicolumn{14}{|c|}{ Miocene } & \multirow{2}{*}{\multicolumn{4}{|c|}{ Pliocene }} & \multirow{2}{*}{\multicolumn{2}{|c|}{ Pleistocene }} \\
\hline & & & & & & & & Early & & & & & $\mathrm{Mic}$ & ddle & & & & Late & & & & & & & \\
\hline & & & $N_{1}$ & $\mathrm{~N}_{2}$ & $\mathrm{~N}_{3}$ & $\mathrm{~N}_{4}$ & $\mathrm{~N}_{5}$ & $N_{6}$ & $\mathrm{~N}_{7}$ & $\mathrm{~N}_{8}$ & $\mathrm{~N}_{9}$ & $\mathrm{~N}_{10}$ & $\mathrm{~N}_{11}$ & $\mathrm{~N}_{12}$ & $\mathrm{~N}_{13}$ & $\mathrm{~N}_{14}$ & $\mathrm{~N}_{15}$ & $\mathrm{~N}_{16}$ & $\mathrm{~N}_{17}$ & $\mathrm{~N}_{18}$ & $\mathrm{~N}_{19}$ & $\mathrm{~N}_{20}$ & $\mathrm{~N}_{21}$ & $\mathrm{~N}_{22}$ & $\mathrm{~N}_{23}$ \\
\hline \multirow{6}{*}{$\begin{array}{c}\text { Batugamping } \\
\text { Kalkarenit }\end{array}$} & 1 & Orbulina universa & & & & & & & & & & & & & & & & 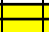 & 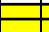 & & & & & & \\
\hline & 2 & Orbulina Bilobata & & & & & & & & & & & & & & & & & & & & & & & \\
\hline & 3 & Globorotalia acostaenea & & & & & & & & & & & & & & & E & 二 & E & E & E & & & & \\
\hline & 4 & Hastigerina aequilateral & & & & & & & & & & & & & & & - & - & 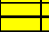 & 二 & $E$ & E & 二 & & \\
\hline & 5 & Globorotalia nepenthes & & & & & & & & & & & & & & & ב & 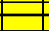 & 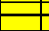 & & & & & & \\
\hline & 6 & Globorotalia menardi & & & & & & & & & & & & & E & & & E & E & Z & E & 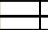 & 二 & & \\
\hline \multirow{6}{*}{$\begin{array}{l}\text { Batulempung } \\
\text { Karbonatan }\end{array}$} & 1 & Orbulina Universa & & & & & & & & & - & & & - & & 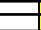 & 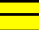 & - & $\square$ & & 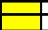 & 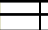 & - & & \\
\hline & 2 & Orbulina Bilobata & & & & & & & & & Z & & & & & & 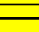 & 二 & E & 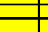 & 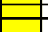 & & - & & \\
\hline & 3 & Globorotalia acostaenes & & & & & & & & & & & & & & & E & - & $E$ & - & $=$ & & & & \\
\hline & 4 & Hastigerina aequilateral & & & & & & & & & & & & & & & 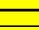 & 二 & 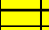 & $=$ & 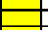 & 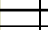 & E & & \\
\hline & 5 & Globorotalia nepenthes & & & & & & & & & & & & & & & & & 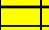 & & 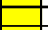 & & & & \\
\hline & 6 & Globorotalia menardi & & & & & & & & & & & & & & & & 工 & & & & & & & \\
\hline \multirow{6}{*}{$\begin{array}{l}\text { Batugamping } \\
\text { Wackestone }\end{array}$} & 1 & Orbulina Universa & & & & & & & & & & & & & & & & & & & & & & & \\
\hline & 2 & Orbulina Bilobata & & & & & & & & & & & & & & & & Z & & & & - & - & & \\
\hline & 3 & Globorotalia acostaenes & & & & & & & & & & & & & & & E & E & E & 二 & 二 & & & & \\
\hline & 4 & Hastigerina aequilateral & & & & & & & & & & & & & & & & - & $\square$ & & - & - & E & & \\
\hline & 5 & Globorotalia nepenthes & & & & & & & & & & & & & & & & 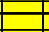 & $\square$ & & - & E & E & & \\
\hline & 6 & Globorotalia menardi & & & & & & & & & & & & & 巨 & Z & & & & & & & & & \\
\hline \multirow{6}{*}{$\begin{array}{l}\text { Batugamping } \\
\text { Grainstone }\end{array}$} & 1 & Orbulina universa & & & & & & & & & & E & 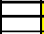 & - & Z & $\pi$ & & $\square$ & 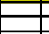 & & E & 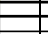 & E & & \\
\hline & 2 & Orbulia bilobata & & & & & & & & & - & & & & & & & 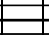 & & & - & & 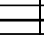 & & \\
\hline & 3 & Globorotalia siakensis & & & & & & & & & & & & & & $\bar{Z}$ & & & & & & & & & \\
\hline & 4 & Orbulina suturalis & & & & & & & & & - & & & & & - & & - & - & & E & 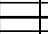 & 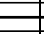 & & \\
\hline & 5 & Globorotalia menardi & & & & & & & & & & & & 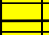 & E & - & & 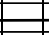 & $\bar{Z}$ & & E & 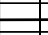 & E & & \\
\hline & 6 & Globigerinoides immaturus & & & & & & & & & & & & & & & & & & & & & & & \\
\hline \multirow{6}{*}{$\begin{array}{l}\text { Batugamping } \\
\text { Packestone }\end{array}$} & 1 & Orbulina universa & & & & & & & & & & & & & & & & & & & & & & & \\
\hline & 2 & Orbulia bilobata & & & & & & & & & & & & & & & & & & & & & & & \\
\hline & 3 & Globorotalia siakensis & & & & & & & & & & & & & & & & & & & & & & & \\
\hline & 4 & Orbulina suturalis & & & & & & & & & & & & & & & & & & & & & & & \\
\hline & & Globigerinoides subquadratus & & & & & & & - & & & & & & 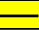 & & & & & & & & & & \\
\hline & & Globigerinoides immaturus & & & & & & & & & & & & & & - & & & & & & & - & & \\
\hline
\end{tabular}

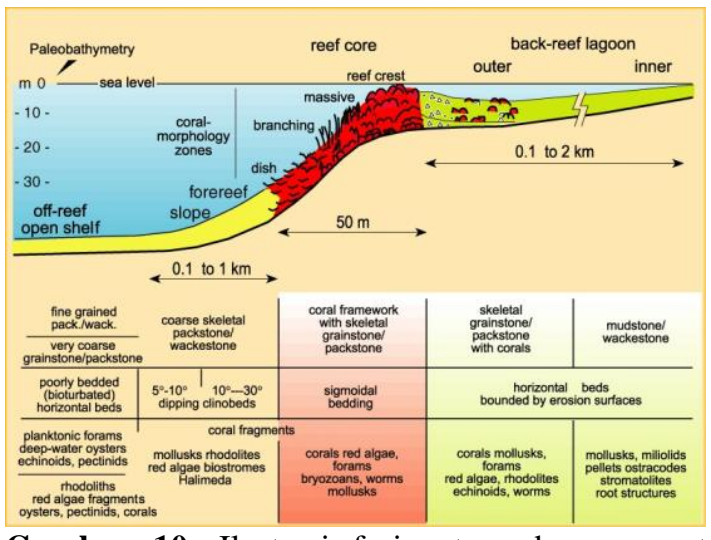

Gambar 10. Ilustrasi fasies terumbu menurut Pomar dkk. (2004).

Berdasarkan deskripsi pada batuan ini dapat diketahui tingkat diagenesisnya. Ukuran butir yang dominan kasar menunjukan bahwa jarak transport material penyusun batuan sedimen karbonat ini dengan pusat terumbu relatif dekat, kebundaran sub-angular, dan terususn oleh butir berupa organisme yang utuh menunjukan tingkat abrasi kurang intens atau pengaruh gelombang tidak dominan. Pemilahan poorly-sorted dengan kemas terbuka menunjukan material yang terendapakan berbeda energi transportnya sehingga terendapkan material dengan ukuran yang beragam. Kontak butir concaveconvex menunjukan bahwa tingkat kompaksi intensif, hal inilah yang mengakibatkan butiran-butiran penyusun batuan ini termampatkan. Selain itu, concave-convex menunjukan proses pelarutan. Komposisi batuan ini mud supported, orthocem berupa sparite menunjukan lingkungan pengendapan berenergi tinggi. Sparite menunjukan proses diagenesis tinggi. Semen kalsit menunjukan bahwa telah terjadi rekristalisasi material authogenic dari mineral aragonit maupun dolomit. Semen kalsit terbentuk hasil pelarutan batuan dengan air meteorik. Satuan litologi packestone menurut Pomar $\mathrm{dkk}$ (2004) terendapkan di fasies fore reef bagian dalam yang semakin dalam fasiesnya menyebabkan keberadaan matriks berupa micrite yang semakin besar dikarenakan arus yang semakin tenang ke arah dalam. Pada fasies ini material karbonatnya berasal dari pecahan ataupun fragmen dari fasies reef front.

\section{KESIMPULAN}

Variasi litologi yag ditemukan di lapangan adalah Satuan Batupasir Karbonatan, Satuan Batugamping Kalkarenit, Satuan Batulempung Karbonatan, Satuan 
Batugamping Wackestone, Satuan Batugamping Grainstone, dan Satuan Batugamping Packestone. Satuan litologi Grainstone dan Packestone terendapkan di fasies Fore reef.

Satuan Batugamping Kalkarenit memiliki kisaran umur N15-N17 atau setara dengan umur Miosen Akhir. Satuan Batulempung Karbonatan berumur Miosen akhir hingga Pliosen awal (N15-N18) dan zona batimetrinya adalah zona neritik. Satuan Batugamping Wackestone memiliki umur Miosen Akhir (N17-N18) dan lingkungan pengendapan berupa zona Neritik. Satuan Batugamping Grainstone berumur Miosen Tengah (N12-N14) dan lingkungan pengendapannya berada di lingkungan neritik. Satuan batugamping packestone berumur Miosen Tengah (N9-N13) dan lingkungan pengendapannya berada di lingkungan neritik. Satuan Batupasir Karbonatan mendominasi sisi timur lokasi penelitian dengan luasan sekitar $25 \%$. Luasan area Satuan Batugamping Kalkarenit tidak terlampau luas yaitu kurang dari 10\% sekitar 5\%. Satuan Batulempung Karbonatan berkisar antara $15 \%$ dari total area lokasi penelitian dengan pola persebaran yang tidak terkumpul di satu lokasi. Satuan Batugamping Wackestone berada di sisi barat daya di Desa Tanjungharjo lokasi penelitian dengan luasan area sekitar 20\%. Luasan area Satuan Batugamping Grainstone ini kurang lebih $20 \%$ dengan sebaran di bagian tengah lokasi penelitian. Satuan Batugamping Packestone ditemukan di bagian tengah hingga utara lokasi penelitian dengan luasan area sekitar $15 \%$

\section{UCAPAN TERIMA KASIH}

Penulis mengucapkan terima kasih kepada Keluarga Bapak Kiswoyo selaku Camat Kecamatan Todanan yang telah memberikan tempat penginapan selama proses kegiatan observasi lapangan berlangsung, juga reviewer yang telah bersedia mereview.

\section{DAFTAR PUSTAKA}

Aditya, R. N., 2019. Geologi Dan Studi Biostratigrafi Foraminifera Plankton Formasi Wonocolo Dan Ledok Kecamatan Todanan, Kabupaten Blora, Provinsi Jawa Tengah. Thesis Magister
Universitas Pembangunan Nasional Veteran, Yogyakarta

Brahmantyo, B. dan Bandono, 2006. Klasifikasi Bentuk Muka Bumi (Landform) untuk Pemetaan Geomorfologi pada Skala 1:25.000 dan Aplikasinya untuk Penataan Ruang, Jurnal Geoaplika, Vol. 1, No. 2, hal. 71 78.

Embry, A. F. dan Klovan, J. E., 1971. A late Devonian reef tract on northeastern Banks Island Northwest Territories. Bulletin Canadian Petroleum Geologists, v. 19, p. 730-781

Pomar, L., Brandano, M., dan Westphal, H., 2004. Environmental Factors Fnfluencing Skeletal Grain Sediment Associations: a Critical Review of Miocene Examples from the Western Mediterranean, Sedimentology, volume 51 issue 4, 627 651

Pringgoprawiro, H., 1983. Stratigrafi cekungan Jawa Timur Utara dan Paleogeografinya: sebuah pendekatam baru, Disertasi Doktor. ITB.

Ramdaniya, D. Irianto, S., dan Kadarisman D.S., 2018. Geologi Daerah Kanjengan dan Sekitarnya, Kecamatan Todanan, Kabupaten Blora, Jawa Tengah, Jurnal Online Mahasiswa, Universitas Pakuan

van Zuidam, R. A.. 1983. Guide to Geomorphology Aerial Photographic Interpretation and Mapping. Enshede: The Netherland (dengan modifikasi). 
